\title{
Number and activity of inflammatory cells in bronchoalveolar lavage fluid in asthma and their relation to airway responsiveness
}

\author{
C KELLY, C WARD, C S STENTON, G BIRD, D J HENDRICK, E H WALTERS \\ From the Departments of Medicine and Immunology, Newcastle General Hospital, Newcastle Upon Tyne
}

ABSTRACT Bronchial responsiveness to inhaled methacholine was measured four to six days befor fibreoptic bronchoscopy in 22 asthmatic patients (10 smokers) and 20 control subjects (12 smokers) The asthmatic patients had a baseline $\mathrm{FEV}_{1}$ greater than $60 \%$ predicted and a $\mathrm{PD}_{20} \mathrm{FEV}_{1}$ (provocatives dose of methacholine causing a $20 \%$ fall in $\mathrm{FEV}_{1}$ ) of $0.006-3.7 \mathrm{mg}$. The 20 control subjects ha® normal pulmonary function and a $\mathrm{PD}_{20} \mathrm{FEV}_{1}$ above the maximum cumulative dose of methacholin $\overrightarrow{\mathbb{Q}}$ of $6.4 \mathrm{mg}$. Bronchoalveolar lavage of a middle lobe segment (lingula in four subjects) was performe $\$$ with three sequential $60 \mathrm{ml}$ aliquots of sterile saline. Cellular metabolic activity was stimulated with latex in aliquots of resuspended cells, and measured by means of luminol enhanced chemilumines $\$_{0}^{\circ}$ cence to assess neutrophil activity and lucigenin enhanced chemiluminescence to assess macrophage activity. Mean absolute total cell counts were similar in the asthmatic and control groups but therE were differences in differential cell counts, with a significant increase in eosinophil $(p<0.05)$ and lymphocyte $(\mathrm{p}<0.05)$ counts in asthma. $\mathrm{PD}_{20} \mathrm{FEV}_{1}$ was negatively correlated with percentage neutrophil counts $(p<0.005)$. Luminol enhanced chemiluminescence/1000 neutrophils wa\& increased about twofold in asthmatic subjects $(\mathrm{p}<0.001)$, but was not correlated with PD $_{20}$ FEV Lucigenin enhanced chemiluminescence/1000 macrophages was increased nearly fourfold i asthmatic patients $(\mathrm{p}<0.001)$ and showed a negative correlation with $\operatorname{PD}_{20} F_{E V}(\mathrm{p}<0.01)$. The macrophage count was increased twofold in current smokers in both groups, but other cell number were not altered significantly. Smoking did not affect cellular metabolic activity in either group. This study supports the idea that an inflammatory process is present in the airways of those with asthmae and suggests a relation between bronchial responsiveness and both neutrophil numbers an\& macrophage activity.

\section{Introduction}

Inflammatory change within the airways, recognised as a histopathological feature of asthma for many years,' has more recently been proposed as an important factor in the development of bronchial hyperresponsiveness in man. ${ }^{2}$ Studies of the development of cellular inflammation in animal airways after exposure to ozone ${ }^{4}$ and specific allergen ${ }^{5}$ have shown an association between the induction of transient airway hyperresponsiveness and neutrophil influx. When the cellular inflammatory response was prevented by prior neutrophil depletion the development of bronchial hyperresponsiveness was

Address for reprint requests: Dr E H Walters, Chest Clinic, Newcastle General Hospital, Newcastle upon Tyne NE4 6BE.

Accepted 25 May 1988 inhibited. ${ }^{67}$ The importance of an inflammatory ce influx in the development of increased airwa 3 responsiveness has, however, been disputed in other animal models. $^{8}$

Lavage has now been performed in patients wit asthma in several centres, and has been generally weff tolerated.' Increased numbers of eosinophils have been recovered in lavage fluid from patients with allergic asthma ${ }^{9-12}$ and during allergen induced late asthmatic reactions. ${ }^{1314}$ Increase in neutrophils has also been found in lavage fluid from patients witt asthma before ${ }^{14}$ and after allergen challenge ${ }^{1214}$ an after inhalation of ozone ${ }^{10}$ and toluene diisocyanate, and mast cell numbers are increased in lavage fluid in atopic patients ${ }^{16-18}$ and may be related to bronchiaf responsiveness. ${ }^{17} 18$

Circulating neutrophils from asthmatic patient $\overrightarrow{\$}$ may be activated after challenge with allergen, ${ }^{1920}$ and 
this increase in activation may be inhibited by steroids. ${ }^{21}$ The degree of activation of pulmonary neutrophils has not been investigated, but increasing in vivo and in vitro evidence suggests that alveolar macrophage function may be enhanced in asthma. ${ }^{223}$ There is little published evidence, however, of a relation between the activity of inflammatory cells in the airway and airway hyperresponsiveness, a feature related to the patient's symptoms and treatment requirements. ${ }^{24}$ Luminol $^{25}$ and lucigenin ${ }^{26}$ enhanced chemiluminescence have been used as markers of reactive oxygen species released during the metabolic burst from neutrophils and macrophages respectively and have been adopted in this study as measures of cell function.

The aims of this study were (1) to compare the cell profile of lavage fluid and the metabolic activity of pulmonary neutrophils and macrophages in 22 patients with stable asthma showing a wide range of bronchial responsiveness and in 20 non-asthmatic subjects; (2) to relate the numbers and activity of inflammatory cells obtained from lavage fluid in the patients with asthma to airway responsiveness measured as the provocative dose of methacholine causing a $20 \%$ fall in $\mathrm{FEV}_{1}\left(\mathrm{PD}_{20} \mathrm{FEV}_{1}\right)$.

\section{Methods}

\section{SUBJECTS}

We studied 22 patients with stable asthma and a wide range of $\mathrm{PD}_{20} \mathrm{FEV}_{1}$ values in response to inhaled methacholine and 20 control subjects with no evidence of airflow obstruction. The mean age of the asthmatic patients was 47 (range 17-73) years and of the controls 53 (range 21-71) years. Ten asthmatic and 12 control subjects were smokers. Ethical approval for the study was obtained from the Newcastle Area Health Authority's ethical committee, with the proviso that all subjects must have a clinical indication for bronchoscopy. The nature of the investigation and details of the procedure were fully explained to each individual, and written consent was obtained. Indications for bronchoscopy among the asthmatic patients included streaking haemoptysis (13), undue cough (8), and possible stridor (1). No asthmatic patient had evidence, before or after bronchoscopy, of a neoplasm, infection, or infarction, and none had recognised bronchiectasis. The control subjects had either a peripheral radiographic abnormality (9), unexplained haemoptysis (6), or cough (5). Four of this group proved to have lung cancer, always on the side opposite to the one that was lavaged. The study followed internationally agreed guidelines ${ }^{27}$ and all subjects fulfilled the following criteria: (1) age 16-75 years, with an $\mathrm{FEV}_{1}$ over $60 \%$ of the predicted value; (2) no oral corticosteroids for at least the previous three months; (3) no evidence of a chest or upper respiratory tract infection within eight weeks.

Medication in the asthmatic patients consisted of regular inhaled bronchodilators alone in nine; seven others had low dose $(<400 \mu \mathrm{g} /$ day $)$ inhaled steroids in addition. Six were receiving no regular treatment. Airway responsiveness to methacholine to a maximum cumulative dose of $6.4 \mathrm{mg}$ was measured in all subjects four to six days before bronchoscopy by a standardised inhalation challenge technique with a microprocessor controlled dosimeter ${ }^{28} \mathrm{~A}$ logarithmic dose-response curve was constructed and the $\mathrm{PD}_{20} \mathrm{FEV}_{1}$ obtained by linear interpolation. Medication was withheld for 12 hours before this test.

Atopy was assessed by performing skinprick tests with house dust mite, grass pollens, and Aspergillus species, and any other antigen for which the subject gave a history suggesting sensitisation. A positive result was recorded if any reaction was greater than that induced by the histamine control.

Spirometry was performed before and 30 minutes after an inhaled dose of $400 \mu \mathrm{g}$ of salbutamol, and single breath transfer factor for carbon monoxide (TLCO) was measured in all current or former tobacco smokers. All the asthmatic patients had an increase in $\mathrm{FEV}_{1}$ of over $15 \%$ after inhaling salbutamol, a normal or raised TLCo value, and a $\mathrm{PD}_{20}$ methacholine value of less than $6.4 \mathrm{mg}$. Thirteen of the 22 asthmatic patients were atopic. None of the control subjects had a measurable $\mathrm{PD}_{20} \mathrm{FEV}_{1}$ with $6.4 \mathrm{mg}$ inhaled

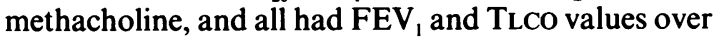
$90 \%$ of the values predicted for age and height. Four subjects were atopic.

\section{BRONCHOALVEOLAR LAVAGE}

Subjects took their usual medication two to three hours before bronchoscopy, which was performed with an Olympus OT10 bronchoscope. No additional bronchodilator was given. Salbutamol was available for inhalation throughout the procedure, but was required after bronchoscopy by only one subject. Asthmatic patients were admitted overnight after lavage for observation. Premedication with intramuscular atropine $0.6 \mathrm{mg}$ and papaveretum $10 \mathrm{mg}$ was given 30 minutes before the procedure and $4 \mathrm{ml} \mathrm{1.5 \%}$ (isotonic) lignocaine was given via a Porta-neb (Medic-aid Ltd) nebuliser compressor unit for 10 minutes before bronchoscopy. Further $2 \mathrm{ml}$ aliquots of $1.5 \%$ lignocaine were administered throughout the bronchoscopy as required. The mean total volume of lignocaine given was 12 (range 8-16) $\mathrm{ml}$. After routine endobronchial examination, and before any specimens were obtained for cytological or histological examination, the bronchoscope was usually wedged in a segment of the middle lobe, but in three control subjects with right sided neoplasia a segment of the 
Table 1 Mean (SD) percentage and absolute cell counts in bronchoalveolar lavage fluid from 22 asthmatic and 20 control subjects

\begin{tabular}{|c|c|c|c|c|c|c|}
\hline Subjects & Total cells & Macrophages & Lymphocytes & Neutrophils & Eosinophils & $\begin{array}{l}\text { Epithelial } \\
\text { cells }\end{array}$ \\
\hline $\begin{array}{l}\text { Percentage counts } \\
\text { Control } \\
\text { Asthmatic } \\
\text { Absolute counts }\left(\times 10^{8} / 1\right)\end{array}$ & & $\begin{array}{l}83.4(10.9) \\
71 \cdot 8 *(15 \cdot 4)\end{array}$ & $\begin{array}{l}12 \cdot 4(9 \cdot 9) \\
20 \cdot 8 *(15 \cdot 1)\end{array}$ & $\begin{array}{l}3.0(2.4) \\
4.4(3.3)\end{array}$ & $\begin{array}{l}0 \cdot 2(0 \cdot 5) \\
1 \cdot 0^{*}(1 \cdot 2)\end{array}$ & $\begin{array}{l}1 \cdot 0(2 \cdot 0) \\
2 \cdot 0(2 \cdot 2)\end{array}$ \\
\hline $\begin{array}{l}\text { Controls } \\
\text { Asthmatics }\end{array}$ & $\begin{array}{l}1.88(1.2) \\
1.90(1.6)\end{array}$ & $\begin{array}{l}1.61(1.0) \\
1.42(1.2)\end{array}$ & $\begin{array}{l}0.19(0.14) \\
0.34 *(0.34)\end{array}$ & $\begin{array}{l}0.06(0.05) \\
0.08(0.06)\end{array}$ & $\begin{array}{l}0.003(0.01) \\
0.022^{* *}(0.03)\end{array}$ & $\begin{array}{l}0.02(0.02) \\
0.04(0.04)\end{array}$ \\
\hline
\end{tabular}

lingula was used. Lavage was performed with three 60 $\mathrm{ml}$ aliquots of sterile phosphate buffered saline at $37^{\circ} \mathrm{C}$. The fluid was aspirated immediately into siliconised glassware by vacuum suction $(50-100 \mathrm{~mm} \mathrm{Hg})$ and kept at $4^{\circ} \mathrm{C}$ until analysis. Supplementary oxygen (4 litres/min) was given throughout the procedure and continued for at least 30 minutes after its completion.

\section{MORPHOLOGICAL STUDIES}

Analysis was completed within two hours of lavage. The specimens were filtered through $200 \mu \mathrm{m}^{2}$ sterile steel mesh to remove mucus. Total cell counts were then performed on each aspirate by two experienced observers using a Neubauer counting chamber and counting a total of 300 cells. The results were expressed as mean values of cells $\times 10^{8} / 1$. As the data were skewed values were logarithmically transformed. The geometric mean ratio between the cells counts for each observer was $0.99(95 \% \quad C L=0.94-1.05)$. The aspirates were centrifuged at $1200 \mathrm{rev} / \mathrm{min}$ for five minutes and the cell pellets resuspended in cell medium 199 at a concentration of $5 \times 10^{8} / 1$. Cell viability was assessed by tryphan blue exclusion, and cytospin preparations were made with a Shandon II Cytospin (Shandon Southern Instruments, Sewickley, PA) using $100 \mu \mathrm{l}$ of cell suspension. The slides were air dried and stained with May-Grünwald-Giemsa and 300 cells were counted by scanning several fields, moving diagonally across the cell preparation to minimise possible artefacts induced by centrifugation. The results were expressed as mean values in absolute $\left(\times 10^{8} / 1\right.$ ) and percentage terms. Monoclonal antibodies to cytokeratin were used to stain several slides at random and confirmed the accuracy with which epithelial cells were being counted in Giemsact stained preparations.

MEASUREMENT OF CHEMILUMINESCENCE

Five hundred microlitres of cell suspension, contain- $c \vec{s}$ ing a calculated 250000 cells, were added to $900 \mu \mathrm{l}$ of $\frac{\mathbb{O}}{O}$ $10^{-4} \mathrm{M}$ solutions of either luminol or lucigenin and $\mathbb{\mathbb { \Phi }}$ warmed to $37^{\circ} \mathrm{C}$. After the addition of $100 \mu$ l of $5 \% \frac{3}{0}$ unopsonised latex particles (Sigma Chemicals), $\stackrel{\Phi}{-}$ chemiluminescence was measured with an LKB $1250 \vec{\bullet}$ luminometer. Assays were performed in triplicate, and $\infty_{\infty}^{\infty}$ the mean peak height was recorded in mv. This was expressed both as total chemiluminescence and as chemiluminescence per 1000 neutrophils for luminol and chemiluminescence per 1000 macrophages for lucigenin to exclude variations due to differing cell $\frac{\circ}{\circ}$ profiles. Lucigenin enhanced chemiluminescence has $\cong$ previously been used to represent alveolar macro- $\overrightarrow{\overrightarrow{0}}$ phage function, ${ }^{29}$ and recent work has shown that, cell 3 for cell, alveolar macrophages produce almost twice as much lucigenin enhanced chemiluminescence as polymorphs. In our mixed cell populations, which consisted largely of macrophages, lucigenin enhanced $\frac{0}{d v}$ chemiluminescence will predominantly reflect $\times$ macrophage activity. ${ }^{30}$ Luminol enhanced $\frac{5}{3}$ chemiluminescence has often been used to assess neutrophil function, ${ }^{25}$ and is not produced in $\frac{0}{3}$ substantial amounts by alveolar macrophages..$^{30}$ The

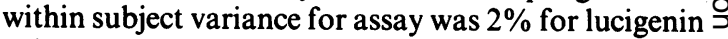
enhanced chemiluminescence and $3 \%$ for luminol $\frac{7}{0}$ enhanced chemiluminescence.

Analysis of variance was used to compare data from 0 asthmatic and control subjects, and for analysis of the

Table 2 Mean (SD) luminol and lucigenin chemiluminescence (CL) in cells from bronchoalveolar lavage fluid in 22 asthmatic and 20 control subjects

\begin{tabular}{|c|c|c|c|c|c|c|c|}
\hline \multicolumn{2}{|c|}{ Total luminol $\mathrm{CL}(\mathrm{mv}) \dagger$} & \multicolumn{2}{|c|}{ Total lucigenin $C L(m v) \dagger$} & \multicolumn{2}{|c|}{ Luminol CL/1000 neutrophils } & \multicolumn{2}{|c|}{ Lucigenin CL/1000 macrophages } \\
\hline Asthmatics & Controls & Asthmatics & Controls & Asthmatics & Controls & Asthmatics & Controls \\
\hline $6 \cdot 77(6 \cdot 2)^{*}$ & $2 \cdot 04(2 \cdot 2)$ & $14.93(14.2)^{* *}$ & $4 \cdot 39(4 \cdot 7)$ & $0.64(0.35)^{* *}$ & $0 \cdot 28(0 \cdot 20)$ & $0.079(0.060)^{* *}$ & $0.022(0.023)$ \\
\hline
\end{tabular}




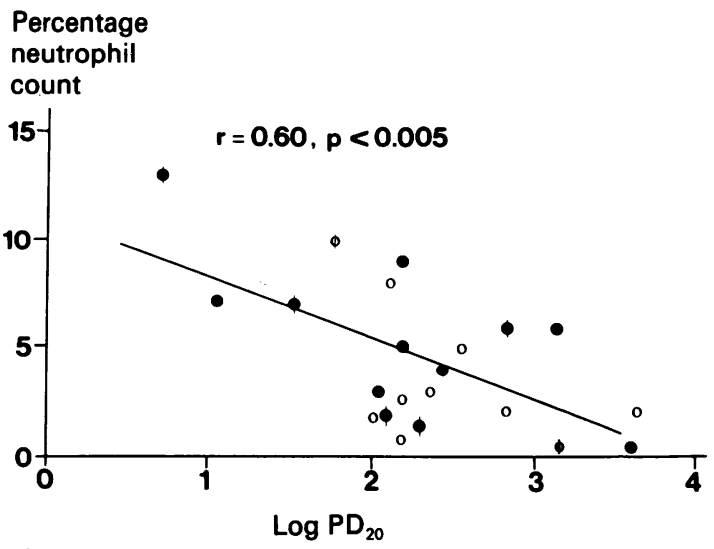

Fig 1 Relation between bronchial responsiveness to methacholine (log $\left.P D_{20}\right)$ and percentage neutrophil counts in bronchoalveolar lavage fluid in 22 asthmatic patients, with the line of regression. Patients not taking regular inhaled corticosteroids: smokers $\bigcirc$; non-smokers 0 ; patients taking regular inhaled corticosteroids: smokers $\Phi$; non-smokers $\phi$.

effects of smoking. All data were logarithmically transformed to reduce skewness. Linear regressions were computed by least squares analysis, after logarithmic transformation of $\mathrm{PD}_{20} \mathrm{FEV}_{1}$ values.

\section{Results}

Bronchoalveolar lavage was well tolerated and none of the subjects developed wheezing. The median total volume aspirated at lavage was similar for the asthmatic (86 (range 11-128) $\mathrm{ml}$ ) and control subjects (89 (range $32-130) \mathrm{ml}$ ). Cell viability was over $92 \%$ in all specimens.

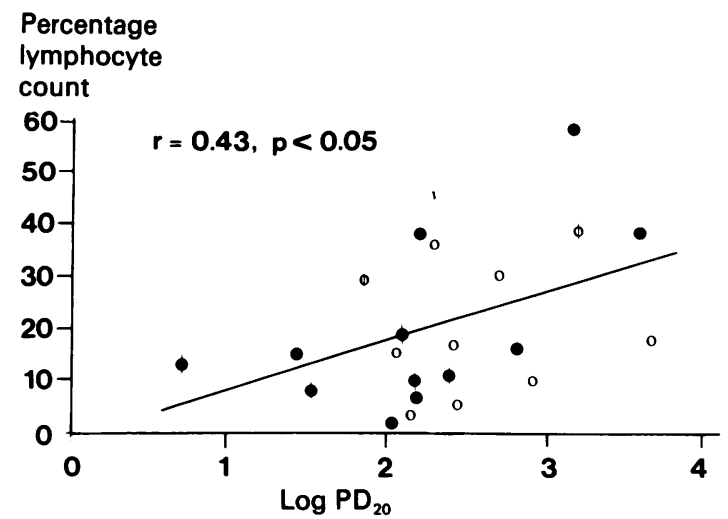

Fig 2 Relation between bronchial responsiveness to methacholine (log $\left.P D_{20}\right)$ and percentage lymphocyte counts in bronchoalveolar lavage fluid in 22 asthmatic patients, with the line of regression. Patients not taking regular inhaled corticosteroids: smokers $\bigcirc$; non-smokers 0 ; patients taking regular inhaled corticosteroids: smokers $\phi$; non-smokers $\phi$.
Lucigenin

$\mathrm{CL}$

(mv/1000

macrophages)

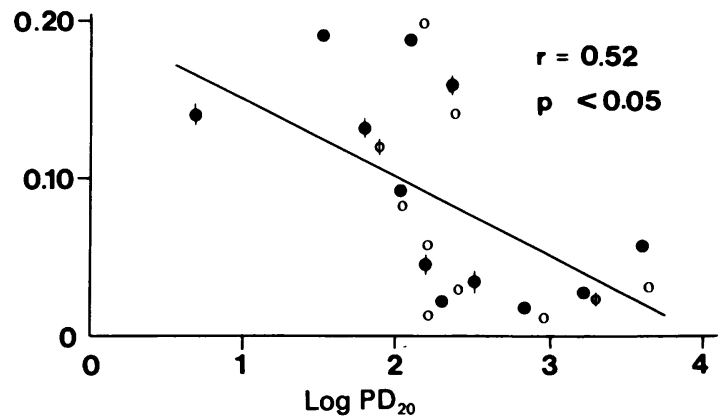

Fig 3 Relation between bronchial responsiveness to methacholine (log $\left.P D_{20}\right)$ and lucigenin chemiluminescence (CL) ( $\mathrm{mv} / 1000$ macrophages) from bronchoalveolar lavage fluid in 22 asthmatic patients, with the line of regression. Patients not taking regular inhaled corticosteroids: smokers $\bigcirc$; non-smokers 0 ; patients taking regular inhaled corticosteroids: smokers $\Phi$; non-smokers $\$$.

\section{LAVAGE CELL PROFILES}

The total cell counts and the absolute numbers of macrophages, neutrophils and epithelial cells did not differ significantly between the two groups (table 1 ). The absolute and percentage eosinophil counts,

Luminol

$\mathrm{CL}$

(mv/1000

neutrophils)

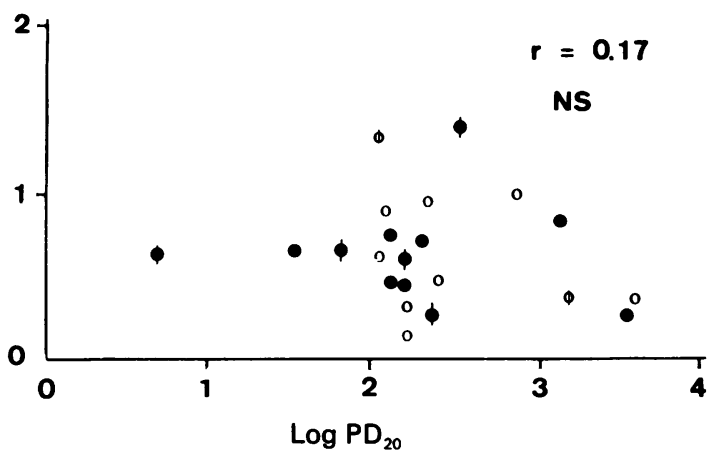

Fig 4 Relation between bronchial responsiveness to methacholine $\left(\log P D_{20}\right)$ and luminol chemiluminescence (CL) (mv/1000 neutrophils) from bronchoalveolar lavage fluid in 22 asthmatic patients. Patients not taking regular inhaled corticosteroids: smokers $\bigcirc$; non-smokers 0 ; patients taking regular inhaled corticosteroids: smokers $\Phi$; nonsmokers 9 . 
Table 3 Effect of smoking habit on the mean (SD) absolute cell counts in bronchoalveolar lavage fluid from asthmatic and control groups

\begin{tabular}{|c|c|c|c|c|c|c|}
\hline & \multicolumn{6}{|c|}{ Absolute counts $\left(\times 10^{8} / l\right)$} \\
\hline & Total count & Macrophages & Lymphocytes & Neutrophils & Eosinophils & $\begin{array}{l}\text { Epithelial } \\
\text { cells }\end{array}$ \\
\hline $\begin{array}{l}\text { CONTROLS } \\
\text { Smokers }(n=12) \\
\text { Non-smokers }(n=8)\end{array}$ & $\begin{array}{l}2 \cdot 32(1 \cdot 13) \\
1.49 *(0 \cdot 77)\end{array}$ & $\begin{array}{l}2.02(1.03) \\
0.99 *(0.53)\end{array}$ & $\begin{array}{l}0.19(0.17) \\
0.19(0.21)\end{array}$ & $\begin{array}{l}0.08(0.06) \\
0.03(0.02)\end{array}$ & $\begin{array}{l}0.005(0.004) \\
0\end{array}$ & $\begin{array}{l}0.03(0.02) \\
0.02(0.01)\end{array}$ \\
\hline $\begin{array}{l}\text { ASTHMATICS } \\
\text { Smokers }(n=10) \\
\text { Non-smokers }(n=12)\end{array}$ & $\begin{array}{l}2 \cdot 58(2 \cdot 17) \\
1 \cdot 33 *(0 \cdot 78)\end{array}$ & $\begin{array}{l}1.98(1.57) \\
0.94^{*}(0.54)\end{array}$ & $\begin{array}{l}0.41(0.47) \\
0.28(0.18)\end{array}$ & $\begin{array}{l}0.09(0.06) \\
0.06(0.06)\end{array}$ & $\begin{array}{l}0.03(0.03) \\
0.01(0.01)\end{array}$ & $\begin{array}{l}0.07(0.07) \\
0.04(0.04)\end{array}$ \\
\hline
\end{tabular}

however, were significantly greater in the asthmatic patients than in the control subjects $(p<0.05)$, as were absolute and percentage lymphocyte counts $(p<0.05)$. Percentage macrophage counts were lower in the asthmatic patients than in the control subjects ( $p<0.05)$, reflecting the other changes.

\section{METABOLIC CELLULAR ACTIVITY}

Mean total luminol enhanced chemiluminescence was greater in the cells obtained from asthmatic patients than in those from control subjects. Mean lucigenin enhanced chemiluminescence was also greater in cells from asthmatic patients than in cells from control subjects. These differences are also highly significant when expressed as chemiluminescence per 1000 neutrophils and per 1000 macrophages respectively (table 2).

RELATION BETWEEN CELL NUMBERS, FEV 1 , AND BRONCHIAL RESPONSIVENESS

Initial $\mathrm{FEV}_{1}$ was not correlated significantly with $\mathrm{PD}_{20} \mathrm{FEV}_{1}$, cell counts, or indices of cellular activity in either group. In the asthmatic patients $\mathrm{PD}_{20} \mathrm{FEV}_{1}$ was correlated negatively with percentage neutrophil counts (fig 1) but not with absolute neutrophil counts $(r=-0 \cdot 17)$. There was a significant positive correlation between $\mathrm{PD}_{20} \mathrm{FEV}_{1}$ and percentage lymphocyte

Table 4 Effect of smoking habit on the mean (SD) luminol (mv/1000 neutrophils) and lucigenin ( $\mathrm{mv} / 1000$

macrophages) chemiluminescence (CL) from cells obtained by bronchoalveolar lavage in 22 asthmatic (10 smokers) and 20 control subjects (12 smokers)

\begin{tabular}{llllll}
\hline & \multicolumn{2}{l}{$\begin{array}{l}\text { Luminol CL/1000 } \\
\text { neutrophils }\end{array}$} & & \multicolumn{2}{l}{$\begin{array}{l}\text { Lucigenin CL/1000 } \\
\text { macrophages }\end{array}$} \\
\cline { 2 - 3 } \cline { 5 - 6 } & Asthmatics & Controls & & Asthmatics & Controls \\
\hline $\begin{array}{l}\text { Smokers } \\
\begin{array}{l}\text { Non- } \\
\text { smokers }\end{array}\end{array}$ & $0.64(0.44)$ & $0.25(0.18)$ & & $0.066(0.057)$ & $0.020(0.024)$ \\
\hline
\end{tabular}

None of the differences between smokers and non-smokers was significant $(p>0.60)$. counts (fig 2) but no significant correlations betweero $\mathrm{PD}_{20} \mathrm{FEV}_{1}$ and macrophage $(\mathrm{r}=0 \cdot 24)$, eosinophif $(r=0.30)$, or epithelial cell numbers $(r=0.03)$.

\section{RELATION BETWEEN CELL ACTIVITY AND} BRONCHIAL RESPONSIVENESS

There was a significant negative correlation betwee bronchial responsiveness and lucigenin chemiluminese cence per 1000 macrophages (fig 3), but not betweenbronchial responsiveness and luminol chemiluminese cence per 1000 neutrophils (fig 4).

\section{EFFECT OF SMOKING ON CELL NUMBERS}

Smoking was associated with an increased total cel count in each group (table $3 ; p<0.001$ ). This was almost entirely due to an increased number of macros phages $(p<0.001)$. There were more neutrophils and eosinophils in smokers than in non-smokers, but these differences did not reach statistical significance.

\section{EFFECT OF SMOKING ON CELL ACTIVITY}

Table 4 shows that smoking had no effect on eitheథ luminol enhanced or lucigenin enhanced chemi luminescence. The relations between $\mathrm{PD}_{20} \mathrm{FEV}$ o and chemiluminescence were also uninfluenced b smoking.

EFFECT OF INHALED STEROIDS ON CELL NUMBERSO AND ACTIVITY

The asthmatic patients who regularly inhaled steroids did not differ in $\mathrm{PD}_{20} \mathrm{FEV}_{1}$ values, cell numbers, o chemiluminescence values from the asthmatic grous as a whole (fig 1-4).

\section{EFFECT OF ATOPY ON CELL NUMBERS AND} ACTIVITY

Atopy had no significant influence on cell numbers of on luminol enhanced or lucigenin enhances chemiluminescence.

\section{Discussion}

In this study we have shown a significant increase 
the numbers of eosinophils and lymphocytes obtained in lavage fluid from patients with stable asthma; the increase in lavage fluid neutrophils was non-significant, though the absolute numbers of neutrophils were much greater than the numbers of eosinophils. The metabolic activity of both neutrophils and macrophages obtained at lavage, assessed by stimulated chemiluminescence, was increased in our asthmatic patients.

An increase in eosinophils in lavage fluid has been described in patients with stable asthma by Godard $e t$ $a l^{9}$ and Tomioka et $a l,{ }^{16}$ and by others in response to a chemotactic or allergic stimulus. ${ }^{1314}$ A correlation between eosinophil numbers and airway responsiveness has also been reported in a small group of individuals with atopic asthma.$^{18}$ Our subjects were generally older than those in the study by Kirby et $a l^{18}$ (47 $v 31$ years). In our study eosinophils were no more numerous in atopic than in non-atopic asthmatic patients and their numbers in lavage fluid did not correlate significantly with bronchial responsiveness. We did, however, find a significant correlation between percentage neutrophil count and bronchial responsiveness in the asthmatic patients, a relationship not previously reported, ${ }^{10}$ although both Fabbri $e t a l^{15}$ and Seltzer $e t a l,{ }^{10}$ using isocyanate and ozone challenges, have described large influxes of neutrophils into the airways in association with the induction of bronchial hyperresponsiveness. Both eosinophils and neutrophils are capable of secreting widely varying inflammatory mediators, including leukotriene B4, prostaglandins, and platelet activating factor; but it is not yet clear which has the predominant role in inducing hyperresponsiveness in the inflammatory reaction found in the airways in man.

Previous studies ${ }^{916}$ have reported an increase in lymphocyte numbers in stable asthma, Godard et al $^{9}$ finding an almost twofold increase in the percentage of lymphocytes in lavage fluid in patients who were similar to ours in mean age and in the amount of lavage fluid recovered. We found a significant positive correlation between the numbers of lymphocytes recovered in lavage fluid and $\mathrm{PD}_{20} \mathrm{FEV}_{1}$. Circulating lymphocytes have been reported to be activated in asthma $^{31}$ and pulmonary lymphocytes are now thought to play some part in mast cell recruitment. ${ }^{32}$ Recently the amount of histamine releasing factor produced by lymphocytes has been shown to be correlated with bronchial responsiveness. ${ }^{33}$ Diaz et al have shown changes in lymphocyte subsets after allergen challenge, ${ }^{34}$ suggesting a possible immune modulating effect. Further studies of lymphocyte markers and function in asthma may clarify their role in this condition.

Like most other workers, we were unable to show any differences in absolute macrophage numbers between asthmatic and control subjects. Godard et al, ${ }^{9}$ like us, reported a decrease in percentage macrophage counts in asthmatic patients, but his absolute numbers did not differ significantly from control values.

We did not count the numbers of mast cells present in our cytospin preparations as estimates of mast cell numbers from slides not specifically prepared for this purpose might have been inaccurate. Several different techniques have been used to fix and stain mast cells, and the numbers recorded in lavage fluid from patients with stable asthma has varied considerably (from $0.25 \%{ }^{16}$ to $\left.3 \%^{17}\right)$. Although mast cells probably play an important part in the development of the early asthmatic reaction, and their numbers in lavage fluid may be correlated with bronchial responsiveness, ${ }^{1718}$ their role in chronic asthma remains to be established. ${ }^{32}$

Seven of our asthmatic patients were regularly inhaling corticosteroids. We could detect no differences in airway responsiveness or lavage results between these patients and the asthmatic subjects as a whole. We are currently investigating their effects on the numbers and activation of cells obtained from the airways of asthmatic patients in more detail.

We have previously shown that filtration of lavage fluid to remove mucus can also reduce cell counts, largely through modest loss of macrophages. ${ }^{35}$ Accurate cell counts and functional studies are difficult to perform in the presence of mucus, and the small resulting change in cell counts was considered a necessary expedient. A chemically inert steel mesh was used rather than the more frequently used cotton gauze to avoid the risk of cell activation. As lavage fluid from all subjects was treated in an identical manner, routine filtration is unlikely to have introduced major inaccuracies.

The production of superoxide radicals by macrophages is an important microbiocidal mechanism ${ }^{36}$ that has been shown to occur after sensitisation with serum from asthmatic patients. ${ }^{37}$ Release of superoxide radicals contributes to inflammation ${ }^{38}$ and they are thought to be predominantly responsible for lucigenin enhanced chemiluminescence, ${ }^{39}$ which has now been used to assess alveolar macrophage activity in several conditions. ${ }^{29} 40$ Lucigenin enhanced chemiluminescence is abolished by superoxide dismutase (unpublished observation). The present results indicate that alveolar macrophage activity is directly related to the degree of airway responsiveness, and suggest a pivotal role for this cell in the pathophysiology of asthma. Evidence that alveolar macrophages have a role in asthma has previously been suggested by the finding of increased levels of $\beta$ glucuronidase $^{41}$ and platelet activating factor ${ }^{22}$ in lavage fluid after local antigen challenge. These 
mediators are thought to be released after macrophage activation via IgE receptors, which have been found in greater numbers on the surface of the alveolar macrophages of asthmatic patients than of control subjects. ${ }^{23}$

Luminol enhanced chemiluminescence is myeloperoxidase dependent, and greatly depressed in patients with myeloperoxidase deficient leucocytes. ${ }^{42}$ A recent study in which luminol enhanced chemiluminescence was increased in lavage fluid cells from asthmatic patients was interpreted as indicating increased macrophage activity. ${ }^{43}$ Granulocyte numbers, however, were closely correlated with luminol enhanced chemiluminescence, suggesting that activity of these cells, and not macrophages, was being measured. This would be in keeping with our findings ${ }^{30}$ and those of Williams and Cole. ${ }^{25}$

We also found luminol enhanced chemiluminescence to be increased in patients with asthma, and interpret this as indicating neutrophil activation. There is already some evidence suggesting activation of neutrophils in asthma. Neutrophil complement rosettes were increased during both early and late asthmatic reactions in patients challenged with allergen. ${ }^{1920}$ These changes were immediately preceded by a rise in circulating neutrophil chemotactic factor in both studies, and could be reversed by corticosteroid treatment, ${ }^{21}$ which also caused a decrease in leukotriene release by stimulated neutrophils. ${ }^{44}$ Our data suggest that neutrophil numbers but not activity are directly related to the degree of bronchial responsiveness. Neutrophils appear to be uniformly active over a wide range of disease activity.

It has been suggested that cellular activity may be depressed in the presence of neoplasia, so the possibility that chemiluminescence was reduced in our four control subjects who had lung cancer must be considered, though the contralateral lung was lavaged in each case. The chemiluminescence results for these subjects were similar to the mean chemiluminescence values for the control group, so neoplasia in these four subjects is unlikly to have affected the group comparisons.

Cigarette smoking is known to cause a twofold to fourfold increase in absolute lavage fluid cell counts, mainly owing to an increase in macrophages ${ }^{45}$ In the present study there was a twofold increase in macrophage numbers in smokers in both the control and the asthmatic group. There were more neutrophils in smokers than in non-smokers, and among nonsmokers the neutrophil count was higher in the asthmatic than the control subjects, though in both cases the changes failed to reach statistical significance. A smoking related increase in neutrophils in lavage fluid has been described previously and may be relevant to the development of flow limitation in smokers. ${ }^{46}$
Smoking did not alter luminol or lucigenin $\stackrel{\vec{P}}{+}$ enhanced chemiluminescence per 1000 neutrophils, but contributed to total chemiluminescence in $\frac{\overline{5}}{\bar{s}}$ asthmatic subjects by increasing cell numbers. Others have found in vivo exposure to cigarette smoke to have $อ$ profound effects on the numbers and function of bothe pulmonary macrophages and circulating neutro- $\overrightarrow{0}$ phils ${ }^{478}$ and, although alveolar macrophages fromsmokers appeared to be generally activated in vivo, $\vec{\omega}$ certain functional characteristics are depressed by? cigarette smoke. ${ }^{49}$ Alveolar macrophages from $\times$ smokers have been reported to have increased glucose $\vec{\omega}$ consumption. ${ }^{50}$ Smoking had no effect on glucoseco oxidation in another study, ${ }^{51}$ however, and, although ${ }_{\infty}^{\circ}$ the production of superoxide appeared to be greater in macrophages obtained from the lungs of smokers, $\rightarrow$ there was no concomitant increase in oxygen con- $\vec{c}$ sumption per cell. More recent work has shown aब significant increase in superoxide production from ${ }_{\mathbb{D}}$ smokers' macrophages only after specific chemical 3 stimulation..$^{52}$ Our data suggest that smoking has no® effect on superoxide generation from macrophages $\vec{\bullet}$ stimulated with $5 \%$ latex.

This study has shown correlations between the $e^{\infty}$ degree of airway responsiveness and the numbers and activity of certain inflammatory cells in lavage fluids from a group of patients with asthma. Although theō function of inflammatory cells in asthmatic airways iső likely to be complex, our findings are consistent with å primary effector role for alveolar macrophages in $\vec{\circ}$ asthma. These have the potential to induce an influx of 3 neutrophils into the airways by the release of chemotactic factors. ${ }^{53}$ Once the neutrophil reaches the airway it appears to be activated to a similar extent across a wide range of airway responsiveness.

We wish to acknowledge the support of the Asthmao Research Council and the District Research Committee for Newcastle upon Tyne.

\section{References}

1 Dunnill MS. The pathology of asthma with speciato reference to changes in the bronchial mucosa. J Clin Pathol 1960;13:27-33.

2 Chung KF. Role of inflammation in the hyperreactivity of the airways. Thorax 1986;41:657-62.

3 Walters EH, Parrish RW, Bevan C, Smith AP. Induction of bronchial hypersensitivity: evidence for a role forO prostaglandins. Thorax 1981;36:571-4.

4 Holtzman MJ, Fabbri LM, O'Byrne PM, et al. Importance of airway inflammation for hyperresponsiveness induced by ozone. Am Rev Respir Dis 1983;127: ${ }^{+}+\frac{+}{+}$
686-90.

5 Marsh WR, Irvin CG, Behrens BL, Larsen GL. $\stackrel{\vec{\Phi}}{\stackrel{D}{*}}$ Pulmonary inflammation and changes in airway@ reactivity after late asthmatic responses in an animal $\stackrel{\mathbb{Q}}{\mathcal{Q}}$ model. Am Rev Respir Dis 1984;129:4-9. 
6 O'Byrne PM, Walters EH, Gold BD, et al. Neutrophil depletion inhibits airway hyper-responsiveness induced by ozone exposure. Am Rev Respir Dis 1984;130:214-9.

7 Murphy KR, Wilson MC, Irvin CG, et al. The requirement for polymorphonuclear leucocytes in the late asthmatic responses and heightened airways reactivity in an animal model. Am Rev Respir Dis 1986;134:62-8.

8 Murlas CG, Roum JH. Sequence of pathologic changes in airway mucosa of guinea pigs during ozone induced bronchial hyperreactivity. Am Rev Respir Dis 1985;131:314-20.

9 Godard P, Aubas P, Calvayrac P, Taib J, Michel FB. Endoscopie et lavage bronchoalveolaire chez l'asthmatique allergique. Nouv Press Méd 1981; 10:3141-8.

10 Seltzer J, Bigby B, Stulbarg M, et al. Ozone-induced change in bronchial reactivity to methacholine and airway inflammation in humans. $J$ Appl Physiol 1986;60:1321-6.

11 Metzger WJ, Moseley P, Nugent K, Richerson HB, Hunninghake GW. Local antigen challenge and bronchoalveolar lavage of allergic asthmatic lungs. Chest 1985;87:155S-7S.

12 Metzger WJ, Richerson HB, Worden K, Monick M, Hunninghake GW. Bronchoalveolar lavage of allergic asthmatic patients following allergen bronchoprovocation. Chest 1986;89:477-83.

13 Bruijnzeel PLB, de Monchy DJR, Verhagen J, Kaufmann HF. The eosinophilic granulocyte-an active participant in the late phase asthmatic reaction? Clin Respir Physiol 1986;suppl 7:54-61.

14 de Monchy JG, Kauffman $H$, Venge $P$, et al. Bronchoalveolar eosinophilia during allergen-induced late asthmatic reactions. Am Rev Respir Dis 1985;131:373-6.

15 Fabbri LM, Boschetto P, Zocca E, et al. Bronchoalveolar neutrophilia during late asthmatic reactions induced by toluene diisocyanate. Am Rev Respir Dis 1987;136: 36-42.

16 Tomioka M, Ida S, Shindoh Y, Ishihara T, Takishima T. Mast cells in bronchoalveolar lavage of patients with bronchial asthma. Am Rev Respir Dis 1984;129:1000-5.

17 Flint KC, Leung KBP, Hudspith BN, Brostoff J, Pearce FL, Johnson NM. Bronchoalveolar mast cells in extrinsic asthma: a mechanism for the initiation of antigen specific bronchoconstriction. $\mathrm{Br} \mathrm{Med} J$ 1985;291:923-6.

18 Kirby JG, Hargreave FB, Gleich G, O'Byrne PM. Bronchoalveolar cell profiles of asthmatic and nonasthmatic subjects. Am Rev Respir Dis 1987;136: 379-83.

19 Durham SR, Carroll M, Walsh GM, Kay AB. Leukocyte activation in allergen induced asthmatic reactions. N Engl J Med 1984;311:1398-402.

20 Carroll MP, Durham SR, Walsh G, Kay AB. Activation of neutrophils and monocytes after allergen and histamine induced bronchoconstriction. J Allergy Clin Immunol 1985;75:290-6.

21 Klempner NS, Gallin JI. Inhibition of neutrophil Fc receptor function by corticosteroids. Clin Exp Immunol 1978;34:137-42.
22 Arnoux B, Simoes Caeiro MH, Landes A, Mathieu M, Duroux P, Benveniste J. Alveolar macrophages from asthmatic patients release platelet-activating factor (PAF-acether) and lyso-PAF-acether when stimulated with specific allergen [abstract]. Am Rev Respir Dis 1982;125(suppl):70.

23 Tonnel A-B, Gosset P, Joseph M, Lassalle P, Dessant JP, Capron A. Alveolar macrophage and its participation in the inflammatory processes of allergic asthma. Clin Respir Physiol 1986;suppl 7:70-6.

24 Juniper EF, Frith PA, Hargreave FE. Airway responsiveness to histamine and methacholine: relationship to minimum treatment to control symptoms of asthma. Thorax 1981;36:575-9.

25 Williams AJ, Cole PJ. Human bronchoalveolar lavage cells and luminol dependent chemiluminescence. J Clin Pathol 1981;34:167-71.

26 Williams AJ, Cole PJ. Investigation of alveolar macrophage function using lucigenin-dependent chemiluminescence. Thorax 1981;36:866-9.

27 Workshop on the investigative use of fibreoptic bronchoscopy and bronchoalveolar lavage in asthmatic patients. Summary and recommendations. Chest 1985;88:136-8.

28 Connolly MJ, Avery AJ, Walters EH, Hendrick DJ. The relationship between bronchial responsiveness to methacholine and bronchial responsiveness to histamine in asthmatic subjects. Pulmonary Pharmacology 1988;1:53-8.

29 Wallaert B, Aerts C, Bart F, et al. Alveolar macrophage dysfunction in systemic lupus erythematosus. Am Rev Respir Dis 1987;136:293-7.

30 Ward C, Kelly CA, Stenton CS, Duddridge M, Hendrick DJ, Walters EH. Macrophage and neutrophil chemiluminescence in bronchoalveolar lavage fluid [abstract]. Clin Sci 1987;73(suppl 17):33-4.

31 Podleski WK, Grimes JR. Circulating hyperreactive lymphocytes in bronchial asthma. Clin Immunol Immunopathol 1976;9:236-9.

32 Holgate ST, Hardy C, Howarth PH, Robinson C, Church MK, Agius RM. Bronchial mucosal mast cells and their implications in the pathogenesis of asthma. Clin Respir Physiol 1986;suppl 7:39-47.

33 Alan R, Kuna P, Rozniecki J, Kusminska B. The magnitude of the spontaneous production of histamine-releasing factor by lymphocytes in vitro correlates with the state of bronchial hyperreactivity in patients with asthma. J Allergy Clin Immunol 1987;79:103-8.

34 Gonzalez MC, Diaz P, Galleguillos FR, Ancic P, Cromwell O, Kay AB. Allergen-induced recruitment of bronchoalveolar helper (OKT4) and suppressor (OKT8) T-cells in asthma. Am Rev Respir Dis 1987;136:600-4.

35 Kelly CA, Ward C, Bird G, Hendrick DJ, Walters EH. The effect of filtration on cell counts in bronchoalveolar lavage fluid [abstract]. Thorax 1986;41:727.

36 Murray HW, Cohn ZA. Macrophage oxygen-dependent antimicrobial activity. J Exp Med 1980;152:1596-609.

37 Joseph M, Tonnel A-B, Capron A, Voisin C. Enzyme rise and superoxide anion production by human alveolar 
macrophages stimulated with immunoglobulin E. Clin Exp Immunol 1980;40:416-22.

38 Oyanagui Y. Inflammation and superoxide production by macrophages. Agents Actions 1980;7(suppl):174-9.

39 Allen RC. Biochemiexcitation: Chemiluminescence and the study of biological oxygenation reactions. In: Adam W, Cilento G, eds. Chemical and biological generation of excited states. New York: Academic Press, 309-44.

40 Wallaert B, Bonniere B, Prin L, Cortot A, Tonnel AB, Voisin C. Primary biliary cirrhosis: subclinical inflammatory alveolitis in patients with normal chest roentgenograms. Chest 1986;90:842-8.

41 Tonnel A-B, Joseph M, Gosset P, Fournier E, Capron A. Stimulation of alveolar macrophages in asthmatic patients after local provocation test. Lancet 1983;ii:1406-8.

42 Rosen $\mathrm{H}$, Klebanoff $\mathrm{H}$. Chemiluminescence and superoxide production by myeloperoxidase deficient leukocytes. J Clin Invest 1976;58:56-60.

43 Cluzel M, Damon M, Chanez P, et al. Enhanced alveolar cell luminol dependent chemiluminescence in asthma. $J$ Allergy Clin Immunol 1987;80:195-201.

44 Gin W, Shaw RJ, Kay BA. Airways reversibility after prednisolone therapy in chronic asthma is associated with alterations in leucocyte function. Am Rev Respir Dis 1985;132:1199-203.

45 Reynolds $\mathrm{HH}$, Newball $\mathrm{HH}$. Analysis of protein and respiratory cells obtained from human lungs by bronchial lavage. J Lab Clin Med 1974;84:559-73.

46 Martin TR, Raghu G, Maunder RJ, Springmeyer MC.
The effects of chronic bronchitis and chronic airflow⿳亠口冋? obstruction on lung cell populations recovered byo bronchoalveolar lavage. Am Rev Respir Dis 1985: 132:254-60.

47 Martin RR. Altered morphology and increased acide hydrolase content of pulmonary macrophages frome

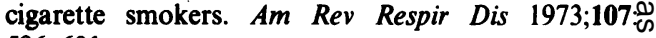
596-601.

48 Harris JO, Olsen GN, Castle JR, Maloney AS: Comparison of proteolytic enzyme activity in $\overrightarrow{-}$ pulmonary alveolar macrophages and bloodo leucocytes in smokers and non-smokers. Am Rev Respir Dis 1975;111:579-86.

49 Holt PG. Immune and inflammatory function in cigarettect smokers. Thorax 1987;42:241-9.

50 Harris JO, Swenson E, Johnson JE. Human alveolar' macrophages: comparison of phagocytic activity, $\rightarrow$ glucose utilization and ultrastructure in smokers and non-smokers. J Clin Invest 1970;49:2086-96.

51 Hoidal JR, Fox RB, Lemarbe PA, Perri R, Repine JE.C Altered oxidative metabolic responses in vitro of alveolar macrophages from asymptomatic cigarette $\vec{D}$ smokers. Am Rev Respir Dis 1981;123:85-9.

52 McLeod R, Mack DA, McLeod EG, Campbell EJ, Estes RG. Alveolar macrophage function and inflammatory $\vec{c}$ stimuli in smokers with and without obstructive airways disease. Am Rev Respir Dis 1985;131:377-84.

53 Gosset P, Tonnel A-B, Joseph M, et al. Secretion of aO chemotactic factor for neutrophils and eosinophils by乏 alveolar macrophages from asthmatic patients. $J$ Allergy Clin Immunol 1984;74:827-34. 